\title{
IDENTIFYing TWENTIETH CENTURY DUdE RANCHES IN THE TETON VALLEY REGION
}
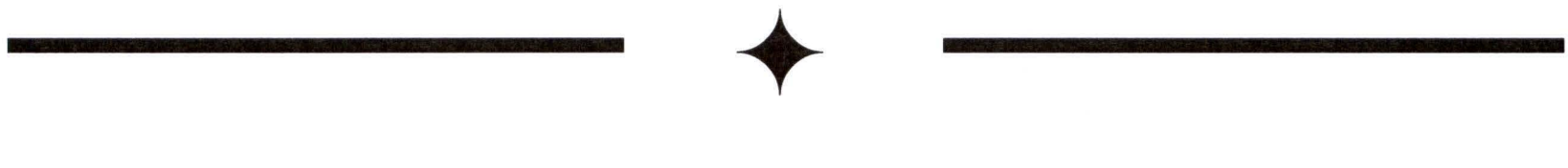

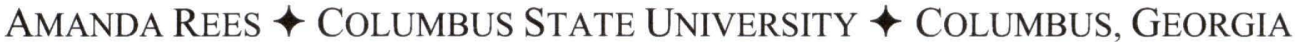

\section{$\downarrow \quad$ INTRODUCTION}

The states of Wyoming, Montana, and to a lesser extent Colorado are commonly understood as the industrial heartland of U.S. dude ranching in the twentieth and twenty-first centuries (Borne 1983). Though there were earlier small scale efforts to host easterners on ranches in the West from the $1850 \mathrm{~s}$ onwards, dude ranching is commonly understood to have begun in 1879 in Medora, North Dakota by the Eaton Brothers (Borne 1983, Rothman 1998). Dude ranching--when outsiders pay to stay on a ranchusually demonstrates most/if not all of the following six characteristics: 1). it embraces of the West's nineteenth century agricultural heritage; 2). it celebrates wild, preserved landscapes; 3 ). it provides an economic vehicle for ranchers to maintain their cultural heritage, and/or investors and managers to have a piece of the American West; 4). it demonstrates a distinct dude ranch aesthetic (architecture, clothing, food, music, stories, education and landscape); 5). it includes horserelated activities; and 6). it provides a safe and contained regional experience transforming the traveler from "mere' tourist status to that of a liminal space inbetween outsider and insider. Since the late nineteenth century Wyoming has developed five centers of dude ranch activity located primarily near mountain ranges, within or close to public lands (National Park Service (NPS) or Forest Service (FS)): 1) Medicine Bow Mountain Range in southeastern Wyoming; 2) Big Horn Mountain Range (eastern and western slopes) in north-central Wyoming; 3) eastern gate region of Yellowstone National Park, northwest Wyoming; 4) Wind River Mountain Range (eastern and western slopes), northwestern Wyoming; and 5) Teton Mountain Range in northwestern Wyoming. My work seeks to establish the extent of dude ranching in Teton Valley.
Jackson Hole dude ranching tourism began in a full-fledged manner in the first decade of the twentieth century. Since then the industry has had a complicated history in the region in particular due to the Grand Teton National Park (GTNP) extension that involved negotiating of the end of most dude ranches in the park. My work is focused on developing a broad sense of dude ranching activity in the Teton Valley that I define as the valley surrounded by the Tetons and Wyoming Range (south of Teton Pass) to west, Hobacks to south, Gros Ventre Range to east, and Absaroka Range to northeast.

\section{$\downarrow$ BACKGROUND}

This assignment extends a previous project conducted several years ago with a grant from the University of Wyoming-National Park Service (UW-NPS) Research Center exploring dude ranch activity in Grand Teton National Park which revealed that in addition to the 17 dude ranches identified by a park historian, there were approximately 13 additional dude ranches that also functioned in the park (Daugherty 1999). Did the park have a monopoly on dude ranching, or was it more broad and widespread throughout the valley?

\section{$\downarrow$ RESEARCH QUESTION}

In an effort to establish a broader context of dude ranching in the Teton Valley, this project asked the simple question: How many dude ranches were operating outside Grand Teton National Park in the Teton Valley/Jackson Hole region during the twentieth century? 


\section{RESULTS}

I identified approximately 30 additional dude ranches in the Teton Valley region, outside the park boundaries, during the twentieth century. This figure together with the approximately 35 dude ranches identified within GTNP, indicates that there were approximately 75 dude ranches of various types that were at one time welcoming dudes to the Teton Valley. This phenomenally large number of dude ranch outfits suggests that the Teton Valley was not only a powerful center for dude ranching and it may be home to the greatest concentration of dude ranches not only in Wyoming but also in the Northern Rocky Mountains. This makes the Teton Valley a particular powerful and useful location to understand dude ranching's rich and complex history.

This work, in combination with research I conducted in Idaho (summer 2008) funded by the Charles Redd Foundation, also suggests that we may need to re-frame thinking about the dude ranch the industry in the Northern Rockies. Traditionally it is the states of Wyoming and Montana that are commonly understood as the industrial heartland of dude ranching in the U.S. States are a central organizing principle in tourism as they have increasingly developed and invested in tourism promotion during the twentieth century. Even our histories are often framed in terms of what occurred within each discrete state. However, if we look at this particular sector of tourism, the logical scale of understanding the dude ranch industry goes beyond state boundaries.

One of the primary magnets for dude ranching in the West has often been its location close or even within the boundaries of federally managed NPS and FS landscapes. Thus a broader context is required. In the particular case of the Teton Valley, this part of the dude ranch industry needs to embrace dude ranch tourism connected to the northern, western and eastern gates of Yellowstone National Park (YNP) as they were all reliant on this federally created space. This would create a region that includes northern Wyoming, eastern Idaho, and southwestern Montana: in other words, the Greater Yellowstone Ecosystem or Region. This region is both a powerful environmentally defined place as well as a culturally defined place in terms of dude ranch tourism in the twentieth century. This work points to a new focus of my research, to develop a cultural history of dude ranch tourism and an assessment of the economic impact of dude ranching to the Greater Yellowstone Ecosystem or Region.

\section{Literature Cited}

Borne, L.R. 1983. Dude Ranching: A Complete History. University of New Mexico Press. Albuquerque.

Daugherty, John. 1999. A Place Called Jackson Hole: The Historic Resource Study of Grand Teton National Park. Moose Wyoming: Grand Teton Natural History Association.

Rees, A. 2005. "A Classless Society": Dude Ranching in the Tetons 1098-1955. Annals of Wyoming. Fall 2-20.

Rodnitzky Jermone. 1968. Recapturing the West: The Dude Ranching American Life. Arizona and the West 10(2), Summer 111-126.

Rothman, Hal. 1998. Devil's Bargains University of Kansas Press. Lawrence.

Roundy, C. 1973. The Origins and Early Development of Dude Ranching in Wyoming: Annals of Wyoming, Spring:5-27. 